\title{
Self-reflexive Identity in Wole Soyinka's Death and the King's Horseman: A Metadramatic Approach
}

\section{By: Nehad Nasr Muhammed Ahmed}

Demonstrator at the Faculty of Languages and Translation

Department of English Language

6th of October University 


\section{Abstract}

This paper attempts to explore the pivotal role of the metadramatic techniques of 'role- playing within the play', 'real life reference within the play', and 'Ceremonies within the play'in presenting the indigenous identity in Death and the King's Horseman (1975) by the Nigerian playwright, Wole Soyinka (1934- ). This is investigated through adopting the literary theory of resistance. "Role- playing" will be investigated through the sarcastic playacting by Yoruba girls to one another in English accent. 'Real life reference' within the play will be tackled through the devices of music, dance, Yoruba metaphorical language, as well as the adoption of a true story into a literary work of art. 'Ceremonies within the play' will be elucidated through showing Yoruba rituals of the king and his horsemen's death. The Nigerian struggle against the colonial/postcolonial practices and the negative consequences that seek to eliminate the indigenous culture and identity by replacing it with the culture of the colonizer will be examined. Hence, the present study will investigate how far the metadramatic devices in the play act as elements of self- reflexive identity against the so called 'English culture crawling'.

\section{Key words:}

British colonization - Wole Soyinka - Nigerian identity literature Metadramatic Techniques -indigenous identity-cultural clashes. 


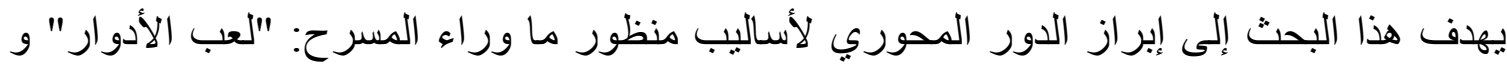

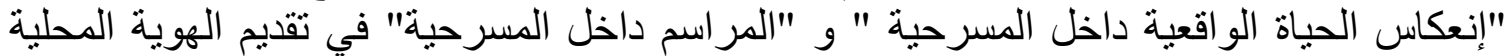

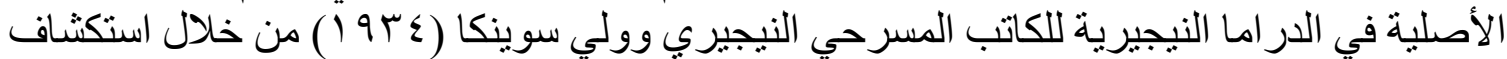

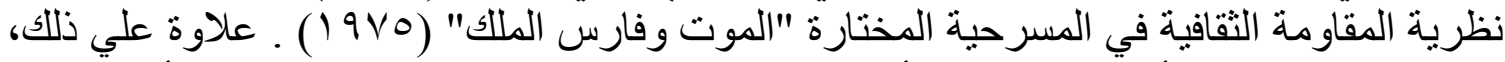

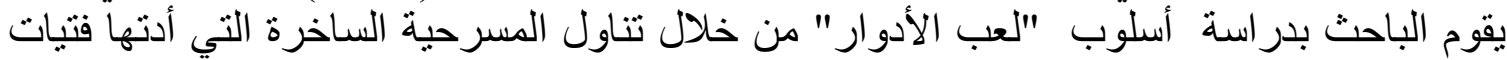

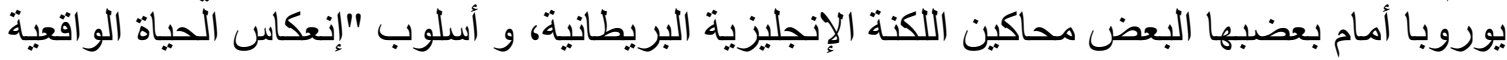

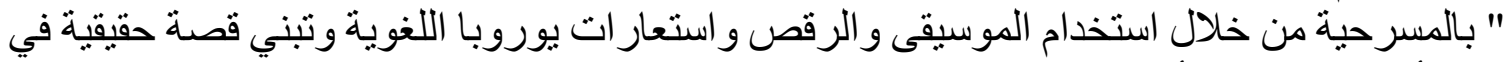

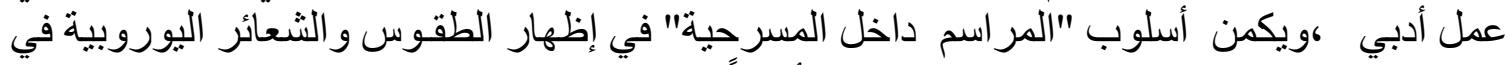

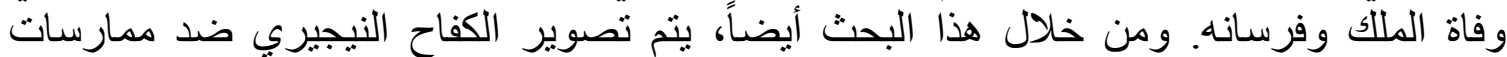

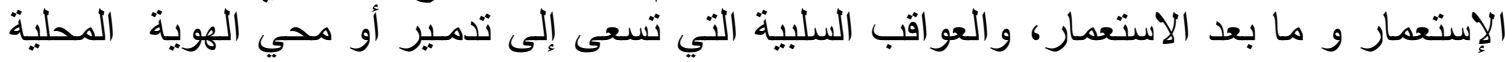

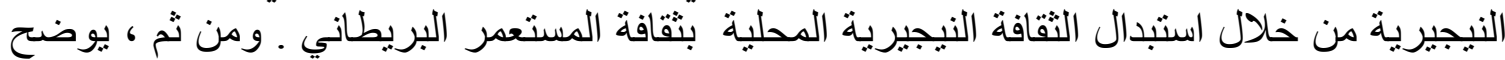

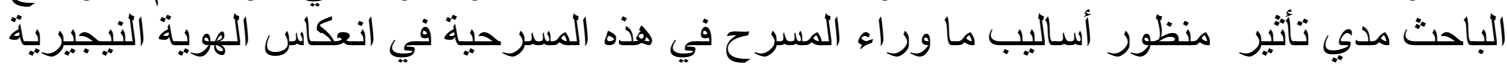
ضد ما يسمى بـ "زحف الئ التقافة الإنجليزية".

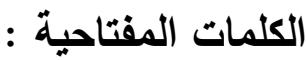

الإستعمار البريطاني - وولي سوينكا - أدب الهوية النيجيرية -أساليب منظور ماوراء المسرح الهوية المحلية - تصادم الثقافات . لمبن 
This paper attempts to explore the pivotal role of the metadramatic techniques of 'role- playing within the play', 'real life reference within the play', and 'Ceremonies within the play' in presenting the indigenous identity in Death and the King's Horseman (1975) by the Nigerian playwright, Wole Soyinka (1934- ). This is investigated through adopting the literary theory of resistance. "Role- playing" will be investigated through the sarcastic playacting by Yoruba girls to one another in English accent. 'Real life reference" within the play will be tackled through the devices of music, dance, Yoruba metaphorical language, as well as the adoption of a true story into a literary work of art. 'Ceremonies within the play' will be elucidated through showing Yoruba rituals of the king and his horsemen's death. The Nigerian struggle against the colonial/postcolonial practices and the negative consequences that seek to eliminate the indigenous culture and identity by replacing it with the culture of the colonizer will be examined. Hence, the present study will investigate how far the metadramatic devices in the play act as elements of self- reflexive identity against the so called 'English culture crawling'.

Concerning the British dominance over Nigeria, Tyler Cowen writes in his essay British colonialism in Nigeria that British colonialism has lasted 60 years from 1901 to 1962 . The British colonizers have sought to do much governmental work in order to change the traditional African authorities through creating a British centralized rule, armed force, and civil service. Yet, the quality of the British job in Nigeria has left Nigeria in immensely poor conditions; since the British colonialism have relied on the import taxes as the essential source to run the colonial state (Cowen).Also, British colonialism has attempted total change in the system of Nigerian administration; since they have refused the Nigerian local control by the traditional chiefs. Hence, the Nigerians have been obliged to abide by the guidance of the British officers. Nigerians have been the hardest natives ever colonized by the British army because they could not delve deeply in the ambiguous Nigerian atmosphere that lies in the exotic native high- colorful customs in the different ceremonies related to wedding and death, religious 
rituals such as the horsemen and chiefs' committing suicide over the death of their king to be buried together after 30 days since the king's death. Furthermore, many changes have followed up with British colonialism, such as building school to teach the Nigerian the English language, and modern British education. Also, the British colonizers have formed new currency and coins, and developed new transportation, and communication systems. Areas with crops such as cacao and peanuts have gained much profits. People have migrated to work in farming or use their western education in order to work in cities in jobs such as wage earners, traders, and artisans.

Despite the security of British colonialism in the first two decades of the 20th century, the British colonizers have struggled to keep control of their Nigerian colony until Nigeria's independence in 1960. Nigerians have protested because of water rates, the collected taxes, and the lack of political representation. The Nigerian Legislative Council that has been established in 1914 and was given limited jurisdiction, was replaced by a larger one in 1922.In the 1920s, a group of Nigerians joined other Blacks in different parts of the world in order to reinforce the project of Pan-Africanism that has worked on liberating Black people from racism and European colonization. Moreover, Herbert Macaulay, the Nigerian nationalist and politician, has established the first Nigerian political party 'the Nigerian National Democratic Party', in 1923. Hence, he is regarded as the 'father of modern Nigerian nationalism'. Also, a national party called 'the Nigerian Youth Movement" has emerged in 1934 to end the British rule in Nigeria. Eventually, Nigeria has attained its independence on October $1^{\text {st }}, 1960$, and that was followed by a federal system with an elected prime minister and a ceremonial head of state (Falola).

During the period of British colonialism, several playwrights such as Femi Osofisan, Bode Sowande, Kole Omotoso, Chinua Achebe, Sefi Atta, Chimamanda Adichie, and Wole Soyinka have sought to reshape Nigerian drama. Wole Soyinka has been one of the most active Nigerian Postcolonial 
playwright. His full name is Akinwande OluWole Soyinka (1934- ). It can be said that his fame is due to his unique style of writing that has created a distinguished position in the Nigerian Anglophone literature that integrates the sublimity of the Shakespearean English and the authenticity of the profound Yoruba metaphors and culture. Yoruba people are ethnic group who inhabit Western Africa mainly in Nigeria. Soyinka is member of the Yoruba people who "in a wide cultural perspective and with poetic overtones fashions the drama of existence" (Markham).

He graduated in 1958, from the University of Leeds in England, with a degree in English literature. He has written his first play A Dance of the Forests in 1963to celebrate the Nigerian independence. He has written several plays The Lion and the Jewel in 1963; The Strong Breed (1963); Kongi's Harvest (1967), The Road (1965), From Zia, with Love (1992), and King Baabu (2002), Madmen and Specialists (1971), Death and the King's Horseman (1975), and The Beatification of Area Boy (1995).

From 1960 to 1964, Soyinka was coeditor of Black Orpheus which is a famous literary journal. He has taught literature and drama since 1960. Soyinka is the first black African playwright to win the Nobel Prize for Literature in 1986. After winning the Nobel Prize, Soyinka has lectured in many universities, and many of his lectures have been published: The Reith Lectures of 2004, such as Climate of Fear (2004). Despite being a playwright, he also has written certain novels: The Interpreters (1965) and Season of Anomy (1973), and several volumes of poetry, such as: Idanre, Other Poems (1967), Poems from Prison (1969), Mandela's Earth and Other Poems (1988); and Samarkand and Other Markets I Have Known (2002). Moreover, his verse has been known for its precise language, lyrics, and the use of meditative poetic forms. The Man Died (1972) is his prose that tells his story of his 22-month imprisonment. His Literature, and the African World (1976) is a collection of essays through which he investigates the role of the artist through the mythology and symbolism of Yoruba. While, his Art, Dialogue, 
and Outrage" (1988) is a critical work on themes related to art and culture. Also, Soyinka has worked in the Encyclopedia Britannica Editorial Board of Advisors from 2005 to 2006 . He has founded and effectively participated in numerous political groups, such as: the 'National Democratic Organization' and the 'National Liberation Council of Nigeria'. Then, he has founded the Democratic Front for a People's Federation in 2010, and he worked as the chairman of that party (Nobel Prize; Kassem 1- 2).

Furthermore, Soyinka is not only a writer, but also an academician who has studied, trained and taught in the universities of the West. It has illustrated the cultural dimensions of the European and Yoruba people. Hence, it has reinforced his consciousness towards the use of literature to portray as well as to resist the negative impacts of British colonialism on the Nigerian Identity. He, through his plays, does not "express the dilemmas of individuals at a personal level but also point to the need of his society to confront the destabilizing of its culture, brought about by imperialism" (Gupta V). Also, he has suggested using Yoruba aesthetic traditions including music, drums, dances and metaphors, and combining them with the Western framework to act as effective mechanism to manifest the cultural clashes between both of them, and to resist the disastrous crawling of the European culture in Nigeria, and to question the nature of the British colonizers.

Soyinka's Death and the King's Horseman is a five - scene play, based on a real incident that took place in Nigeria during British colonial rule, since the horsemen of Yoruba King were not allowed by British colonialism to commit any ritual suicide motivated by traditional, religious or spiritual rituals. The plot of this play is true Yoruba folklore that inspired other popular playwrights such as: Baba Sala and Duro Ladipo. However, Soyinka's version is the most distinctive for two reasons. The first reason is the political setting during colonialism in twentieth century, in Nigeria, while the second reason is the historicity that was captured by the play to complicate and illustrate the tragic paradigm (Ampka 29). In addition, Soyinka has revealed in an 
interview with freelance journalist Simon Stanford, in 2005, that the political activities have influenced his writing; the Nigerian society during British colonialism has slightly declined into the colonial impact of the European culture. However, that colonial cultural impact has failed to get its harmonious co-habitation due to the Nigerian nationalism (Stanford).

Regarding the plot of this play, it unfolds that a Yoruba character, namely Elesin, the King's Horseman cannot fulfill the Yoruba traditional rituals of death, since the death of the king must be accompanied by the ritual death of the king's horseman, dog and horse, in order to help the king's spirit to ascend peacefully to the afterlife. Otherwise, the king's spirit wanders the Earth and disrupts the cosmic order of the Yoruba people leaving their future distorted. Half of the play manifest the process of this ritual with Elesin, a life lover man, who decides that his final day must be celebrated before the ritual process begins. Hence, he decides to marry once again. However, Simon Pilkings, the local British colonial ruler, views these Yoruba ritual suicides as barbaric and illegal. Thus, he orders that Elesin must be arrested to prevent him from such suicide. Iyaloja and Praise- Singer blame Elesin and Pilkings, for such mess that will plague People of Yoruba. They have accused Elesin of being extremely attached to the earth to fulfill his obligatory rituals. So, Olunde, Elesin and Iyaloja's son, who has travelled to England to study medicine, has bravely decided to commit that suicide rituals instead of his dad in order to protect the people of Yoruba from fatal cosmic order distortion Consequently, Elesin feels guilty about his son's suicide. Thus, Elesin decides to commit suicide so that he departs in degradation in the next world.

Death and the King's Horseman mixes the European literary theatre with the traditional theatre from the Yoruba tribe in Southwest Nigeria in order to reflect the Yoruba cultural identity and its clashes with the European one. Thus, Soyinka decides to make some pivotal changes for more accurate details about the real life of Yoruba during the colonial period by the English authority. The play has been performed at London's Royal National Theatre 
beginning in April 2009 and directed by Rufus Norris. Also, the play has been staged by the St. Louis Black Repertory Theater February 2008. It has been translated to Yoruba language entitled as IkuOlokunEsin, and it has been performed at the National Theater, Lagos Nigeria, and directed by Olusegun Ojewuyi. Hence, it has granted him the honor of being the only director to stage the play in both English and in Yoruba languages (Podollan).

In 1963, Lionel Abelhas published his significant book Metatheatre: A New View of Dramatic Form in which he introduces the theoretical framework of meta-theatre in the early sixties. He classifies all plays except Greek tragedies as examples of 'meta-theatre' because "all of them are theatre pieces about life seen as already theatricalised" (Puchner6). He believes that:

Persons appearing on the stage in these plays are there not simply because they were caught by the playwright in dramatic postures as a camera might catch them, but because they themselves knew they were dramatic before the playwright took note of them. What dramatized them originally? Myth, legend, past literature, they themselves. (Abel 134-35)

The word 'metatheatre' is divided into two parts: 'meta' and 'theatre'; the meaning of 'meta' as 'above' refers to a grand narrative acting as a frame to the layered narrative. The technique of metatheatre or meta-drama has gained its conceptual and theoretical importance in the twentieth century through Lionel Abel, Robert J. Nelson, James L. Calderwood, June Schlueter, Manfred Schmeling, and Richard Hornby. Abel's interpretation of the function of metatheatre has changed the realm of the concept itself; most critics tend to examine the elements of metatheatre with reference to specific periods in literary history. For example, Dieter Mehl's analysis is limited to the English Renaissance to fulfill the 'comic relief'; Manfred Schmeling explores the phenomenological meaning and function of metatheatre, while Richard Hornby "pays attention to the identification or taxonomical categorization of various self-referential techniques such as play-within-theplay and role-play" (Anwar 27). 
Some critics following Abel have tended to look into the philosophical meaning of life through metatheatre; Martin Puchner reinforces Abel's point of view by stating that metatheatre is "not simply something that occurs in the theatre, but also something that encompasses an understanding of the world as theatre, even before it is brought onto the stage" (Nellhaus6). Also, the concept of metatheatre "coincides with the origins of any form of performative situation which involves performers and spectators ranging from religious and socio-cultural ritual enactments, rites of passage, and exorcist practices to developed literary genres such as theatre and drama" (Anwar25). This has been supported and developed by many movements in the history of theatre through performance studies. Hence, Niall Slater argues in his book Spectator Politics: Metatheatre and Performance in Aristophanes that 'metatheatricality', in moderndrama, is "fundamentally an experience of performance" (2).

Metadrama or metatheatre is "widely regarded as drama about drama or theatre about theatre, producing self-conscious moments by which a play draws attention to its fictionality" (Anwar 19). It is a method that enables the author or playwright to create double framed performances to refer back to his/her artistic attempts which in turn create an effective distance of audience from his or her play. Regarding the difference between 'metatheare' and 'metadrama', there is confusion over the dramatic history of metatheatre owing to the way it has been termed variously by many critics. The terms metadrama and metatheatre are used interchangeably by many, Calderwood calls metatheatre "a species of metadrama" that "explores the nature of contextual form and function of aesthetic distancing" (Calderwood 5). In this respect, he grants metadrama a status higher than metatheatre in terms of an 'all-encompassing theoretical basis'. Moreover, the distinction between 'metatheatre' and' metadrama' is not based nonexclusive categorization but on the degrees of spatial (time and space) and thematic limits of theatre. The following quotation is illustrative: 
Metatheatre reflects the logistics of the performance arena, while metadrama includes actual performance, the literary value of the written script, and by extension the meta quality of life. However, this distinction results in 'theoretical reductionism' since in most cases theatrical representations are informed and constructed on a textual basis. Hence, metatheatre is not only a constituent and an essential element of drama as a literary genre but also of the social drama that has been played in the real life, involving the cultural, religious, economic and artistic behaviors which are re-enacted on the stage. (Anwar 221-22)

Moreover, there has been a great interest in the technique of meta-drama as an element of drama. Although it is rarely given an adequate definition, it is defined by Richard Hornby as 'a drama about drama'. Meta-theatre is not limited to a few playwrights or some periods of drama history. Great playwrights tend to be meta-dramatic than ordinary ones through employing the meta-dramatic devices whether in manifested or hidden ways. They can be regarded as uniquely different from other playwrights. The possible varieties of dramatic elements such as 'the play within the play'; 'the ceremony within the play'; 'role playing within the role'; 'literary and real life-reference within the play'; 'self-reference'; 'analepsis' (Flashback ); and 'footnote' are all generally considered as metadramatic techniques. They are also devices to create distance; "they do not only refer to the illusive and theatrical nature of a performance but also reflect upon the art of playwriting itself and help in the dissolution of generic and theatrical boundaries" (Anwar 19).

Metadramatic devices: 'role- playing within the play'; 'real-life reference'; Literary reference within the play; and 'ceremony within the play' produce effective self- conscious moments; they enable the author or playwright to express reality and to create double framed performances to refer back to his/her artistic attempts which in turn create an adequate distance of audience from his or her play. Consequently, great veteran playwrights tend 
to be metadramatic than ordinary ones through employing the meta-dramatic devices whether in a manifested or hidden ways, so they can be regarded as uniquely different from other playwrights.

Richard Hornby, in his book Drama, Metadrama and Perception, writes that there is a role- play within the action of the play itself, when a character for some reason plays a role that is different from himself or herself. It is an artistic means to portray the characters; by "showing not only who the character is, but what he or she wants to be. When the playwright describes or depicts a character that is himself playing a role, this role is closer to the character's true self than his everyday real personality" (Hornby 68).

Additionally, he explains that the real-life reference includes allusion to real persons, living or dead; real places; real objects; real events, citation, allegory, parody, and adoption. "Citation means a direct quotation of real- life person's words, or depiction of such a person as himself, or the depiction of real life objects, places, or things as themselves" (Hornby 93). It acts as a tool to satirize a certain situation in life, while the real- life persons are depicted as their real selves with their real names, and it also adopts characters that have frames of reference in the real world. Hence, their allegorical roleplaying reflects upon the prevailing socio-political circumstances.

Regarding the metadramatic technique of 'ceremony within the play', they contain funerals, feasts, games, festive rituals, weddings, tournaments, games, rituals, trials, inquests, processions, and coronations. "Tragedies do not end with such festive and harmonious ceremonies; however, they do not lack for ceremonies of other types in other parts of the play" (Hornby 51). Ceremonies are highly common in the historical plays. There is blurring that occurs when one tries to classify the ceremonies as it is observed in Othello's murder of Desdemona because it has a ceremonial and meta-dramatic sense. 
The metadramtic devices: 'role- playing within the play; 'real-life reference', and 'ceremony within the play', on the one hand, alienate the audience from the actions of the main play to engage them in another different thing or another pivotal message. They are double-layered methods that function as indirect effective mechanism to resist the negative Colonial/Postcolonial practices in the Nigerian culture such as "English culture crawling". The cultural resistance is thus made clear by reflecting and keeping their own Nigerian indigenous identity alive. The use of Yoruba indigenous language "authenticates their experiences and seeking to tap into their views and values and mindset" (Minter).

Concerning the use of the metadramatic device 'role- playing' within the play in Soyinka's play, it is evident in Scene iii when the sergeant Amusa orders women and Iyaloja (Elesin's wife) to stop the noise of drumming and manages to arrest the chief Elesin Oba for his criminal intent which is commenting suicide as part of the Yoruba rituals traditions over the death of their king. The women and Iyaloja cared about Amusa's orders of drumming and arrest of Elesin Oba. They instead defended Elesin's situation as they reply that the drumming and noise is for Elesin Oba's wedding new wife, and they celebrate his merry moment by dressing him best clothes. Then, Iyaloja's girls make fun of Amusa for not attending the Elesin's wedding without invitation in a play-acting role in an English accent to one another and the older women support their role with their laughter as follows:

Girls (In turn. In an English' accent): Well well it's Mister Amusa. Were you invited? (Play-acting to one another. The older women encourage them with their titters.)

Your invitation card please?

Who are you? Have we been introduced?

And who did you say you were?

Sorry, I did not quite catch your name.

May I take your hat? 
Never known a native tell the truth.

Does it get rather close around here?

...

\section{Ha hahaha}

Ha hahaha (Soynika 37-38)

The role - playing acted by Iyaloja's girls might seem a humourous scene that mocks sergeant Amusa, but it is, indeed, an effective mechanism of resistance. Through that virtual scenario between the girls, it turns out that they make fun not only of sergeant Amusa but also of the British colonizers who claim that they are the only civilized people who abide by the modern roles, and call the native Yoruba people uncivilized because they are barbaric and make huge fuss over everything and do not tell the truth. Even when they attend ceremonies, they do not use invitations. Yoruba girls, instead of showing anger over the British claims about them, mock them with the same claims. Their use of "Ha haha" at the end of the played scenario elucidates how far they are courageous, stubborn and powerful so as to treat English colonizers in a master to master relationship. This reinforces and reflexes their pride of their Yoruba identity.

In terms of investigating the metadramatic device of 'real-life reference within the play', the play adopts a true story that has taken place in the Colonial period in Nigeria. The use of songs, dance and stronglymetaphorical speeches clearly reflect the Yoruba cultural identity. Regarding the concept of adoption as a mechanism to maintain Yoruba identity. Soyinka clearly states through the notes of the play is based on real events happened in 1946, in an ancient Yoruba city in Nigeria called "Oyo". During that year, the lives of Elesin (the father), Olunde (the son) and the Colonial District Officer are woven together into horrid results illustrated through the incidents. However, he (Soyinka) tends to make some changes in sequence, details and characterization. Even he delays the action for two or three years to coincide the time of war in order to fit the dramaturgical reasons (Soyinka). 
Hence, Soyinka's adoption is not accidently created; it is a meant-to-be process of writing in order to highlight the distinguished Yoruba real identity through accentuating a true story that has happened in the Yoruba society during the Colonial period in Nigeria. It also manifests the cultural clash between two different cultures: Yoruba Nigerian culture and the English Western culture. It is interesting to notice that Soyinka has made the play look like a book that corroborates two parts happening at the same time; part of the play tackles songs, dances and an extremely eloquent metaphorical language and expressions of the Yoruba identity, while the other part tackles the Western life style of the English people.

In Death and the King's Horseman, language reinforces and archives the colonial past history as it reflects the African political phases: the precolonial, the colonial and the postcolonial. The pre-colonial period is manifested in the dominance of the world of gods and ancestral spirits; the Colonial period demonstrates the Western cultural imperialism; whereas the post-colonial period shows the powerful struggle of the indigenous Africans. Soyinka's choice for the setting and characters are rooted in the Nigerian Yoruba tradition, even the choice of the characters' names such as: PraiseSinger; Elesin Oba, Iyaloja, Olunde Drummers, Women and the Young girls reflect the era within which the incidents have happened in Yoruba (Boluwaduro 99).

The Yoruba character of Praise - Singer adopted from a true life story shows despise for British colonization. In the beginning of the play, white slavers distort the peacefulness of Yoruba by imposing their own culture and wars, which demolish the authenticity of the Yoruba race in Nigeria. The following quotation is relevant:

the white slavers came and went, they took away the heart of our race, they bore away the mind and muscle of our race. The city fell and was rebuilt; the city fell and our people trudged through mountain and forest to found a new home. (Soyinka 10)

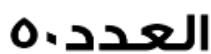


This quotation indicates the real feelings of a man from Yoruba towards the white British who try to replace the distinguished identity of Yoruba for a new Western one.

Olunde, Elesin's son, the real - life character that has been embodied in this play, possesses his Yoruba family's stubbornness, wisdom, sharpness and powerful personality. He has travelled to study medicine in England. However, he respects his dad's sacrifice for his people, has maintained his Yoruba identity as he is part of it. The following dialogue between Olunde and Mrs. Pilkings (Jane) is illustrative:

Jane: Oh, this. I t's caused quite a stir I assure you, and not all of it very pleasant. Yom are not shocked I hope?

Olunde: Why should I be? But don't you find it rather hot in there?

Your skin must find it difficult to breathe.

Jane: Well, it is a little hot I must confess, but it's all in a good cause.

Olunde: No I am not shocked Mrs. Pilkings. You forget that I have now spent four years among your people. I discovered that you have no respect for what you do not understand. (Soyinka 50)

Olunde's answer to Jane shows that he is a proud powerful Yoruba man who faces the English people with their major defect which is being ignorant to whatever they do not know, they call it barbaric or a native stuff. Historically, however, the British colony's denial towards what they do not know about the Nigerian culture and rituals has been one of the main reasons beyond the failure of the British rule in Nigeria.

Moreover, Olunde's reply to Jane in a strongly- toned voice manifests his total refusal to be called smart or wise just because he has studied Western sciences in England:

Olunde: How can I make you understand? He has protection.

No one can undertake what he does tonight without the deepest protection the mind can conceive. What can you offer him in place of 
his peace of mind, in place of the honor and veneration of his own people?

Jane: I see. So it isn't just medicine you studied in England.

Olunde: Yet another error into which your people fall. You believe that everything which appears to make sense was learnt from you.

(Soyinka 53)

Olunde does not believe in the English people claim that whatever logical or makes sense must be English or Westernized. He contends that that following rituals or beliefs do not make one a fool, but they make him/her authentic tohis/her native identity.

Olunde's dialogue with Mrs. Pilkings in Scene iv clearly manifests his personality as a responsible intellectual man who does not care about surviving, if it contradicts the mass survival of his people. He even faces Mrs. Pilkings with the fact that the English people are highly brilliant in surviving no matter. However, he perceives it as a type of cowardice with no real honor of being remembered after death:

Olunde: Others would call it decadence. However, it doesn't really interest me. You white races know how to survive; I've seen proof of that. By all logical and natural laws this war should end with all the white races wiping out one another, wiping out their so-called civilization for all time and reverting to a state of primitivism the like of which has so far only existed in your imagination when you thought of us.

Jane: Through ritual suicide?

Olunde: Is that worse than mass suicide? Mrs. Pilkings, what do you call what those young men are sent to do by their generals in this war? Of course you have also mastered the art of calling things by names which don't remotely describe them. (Soyinka 53- 54)

Thus, Olunde's traits of heroism, bravery and responsibility are made clear. In addition, it can be said that Olunde's words pave the way for the acceptance 
of his sacrifice of his soul to let the king's spirit find its final rest in afterlife. This is done for the sake of preventing and protecting his people of Yoruba from serious consequences such as cosmic order disruption.

It is noticed that the characters of Yoruba such as Elesin Oba and Iyaloja tend to express their emotions and happiness by dancing round and singing. Elesin expresses his excitement and enthusiasm towards the epic role of self- sacrifice that he is about to do as a king's chief. He sings the story of the" Not- I- Bird", and dances accompanied by unique rhythm out of his steps over the music of drums as he changes his voice patches to fit song's characters with full energy and fun:

Death came calling.

Who does not know his rasp of reeds?

A twilight whisper in the leaves before

The great araba falls? Did you hear it?

Not I! Swears the farmer

...

'But now he pauses, suddenly

Let's out a wail: 'Oh foolish mouth, calling

Down a curse on your own head! Your lamp

Has leaked out all its oil, has it?' (Soyinka 11-12)

Accordingly, expressing the real life of Yoruba through music and dancing does not only depict the Yoruba cultural identity, but it also accentuates the African experience versus the practical European one. The people of Yoruba tend to celebrate their moments with expressive songs, lyrically accompanied by dancing at the same time. Males and females of Yoruba sing and dance with the same attitude. They like group singing and dancing. Iyaloja and the other women dance around while singing in the presence of Elesin and Praise - Singer:

Iyaloja: (dancing round him. Sings):

He forgives us. He forgives us. 
What a fearful thing it is when

The voyager sets forth

But a curse remains behind

Women: For a while we truly feared

Our hands had wrenched the world adrift

In emptiness.

Richly, richly, robe him richly

The cloth of honour is alari

Praise- Singer: He who must, must voyage forth

The world will not roll backwards

It is he who must, with one

Great gesture overtake the world (Soyinka 16-17).

Soyinka's mentioning of "alari Sanyan" can be considered as a real- life reference to the Yoruba culture of dressing in ceremonies since it is a fabric of cloth used in special events and mostly pink. That fabric is an essential part of the Yoruba ceremonial identity.

The cultural clash between the people of Yoruba and the British people when it comes to celebrations can be easily observed when the British couple Simon Pilkings and his wife dance Tango in the Verandah. The following stage directions in Scene ii are relevant:

The verandah of the District Officer's bungalow. A tango is playing from an old hand-cranked gramophone and, glimpsed through the wide windows and doors which open onto the forestage verandah are the shapes of Simon Pilkings and his wife, Jane, tangoing in and out of shadows in the living-room. (Soyinka 23)

It can be argued that Soyinka, through that stage direction, attempts to manifest the cultural division and clashes between the Yoruba culture and the British European one. It is illustrated via sketching eminent features of Yoruba culture of celebrating: Yoruba people dance, sing and play drums 
vibrantly, and British European culture of celebrating: the Western English people are just satisfied with dancing some tango in a verandah and some boring music played by old gramophone without any kind of energy or fun.

The use of highly metaphorical eloquent language by Yoruba characters such as Elesin Oba makes their speeches too ambiguous and complicated compared to the language of the English people as the following quotation by Elesin shows:

How can that be? In all $m$ y life

As Horseman of the King, the juiciest

Fruit on every tree was mine. I saw, I touched, I wooed, rarely was the answer No.The honour of my place, the veneration I

Received in the eye of man or woman Prospered my suit and Played havoc with my sleeping hours.

And they tell me my eyes were a hawk

In perpetual hunger. (Soyinka 18)

Elesin's eloquence in expressing his deep feelings remind readers of the tragic hero in the Shakespearean drama who tend to use neat and sophisticated language that surrounds the audience with sublimity and serenity at the same time. Soyinka is known for writing using metaphors in order to delve into the core of meaning.

In addition, the following dialogue at the beginning of scene I between the Praise-Singer and Elesin in the market, when Praise - Singer walks towards the market where the audience are identified with his preparation for the promising ritual of death of Elesin, presents a corroboration of the Standard English and the Nigerian indigenous metaphorical sense:

Elesin Oba enters along a passage before the market, pursued by his drummers and praise-singers. He is a man of enormous vitality, speaks, dances and sings with that infectious enjoyment of life which accompanies all his actions. Elesin (slows down a bit, laughing): A tryst where the cockerel needs no adornment. 
Praise- singer: o-oh, you hear that my companions? That's the way the world goes. Because the man approaches a brand new bride he forgets the long faithful mother of his children.

Elesin: When the horse sniffs the stable does he not strain at the bridle? The market is the long-suffering home of my spirit and the women are packing up to go. That Esu-harrassed day slipped into the stewpot while we feasted. We ate it up with the rest of the meat. I have neglected my women. (Soyinka 9)

It is interesting to notice that the English used in the above- mentioned dialogue sounds like direct translations of Yoruba because readers hardly understand it, since the script is reinforced by highly complicated Yoruba metaphors and imagery that fail to be accurately translated into English.

According to Henry Louis Gates essay "Being, the Will and the Semantics of Death", Soyinka always uses a language of his own. A direct relation between him and Shakespeare is instantly noticed through the depiction of tragedy and the metaphysical structures of death and the nature of existing in life and afterlife. Soyinka has created what is called "Nigerian tragedy" as a mechanism to challenge the Western tragedy. "Soyinka has invented a tragic form, registered in his own inverted language, a fusion of English and Yoruba. Surely, this is his great achievement. The resolution of Death and the King's Horseman stands as a mythic structure, as a restructure of reconciliation" (Gates 75).

Regarding the use of the metadramatic technique of 'ceremonies within the play', it is highly demonstrated through the catastrophic scene of the Yoruba Rituals of self-sacrifice (Committing suicide).Olunde, Elesin's son, who has been sent to England in order to study medicine, returns back home to Yoruba to meet his father (Elesin) alive. Hence, he, as Elesin's heir, decides to restore his family's honour through committing suicide. Although it contradicts the colonial entity (the local British ruler Simon Pilkings) that embarked on arresting Elesin Oba (Chief and king's Horseman) to stop him 
from committing suicide over the death of his king, Olunde immediately decides to take his own life. His decision seems mysterious, barbaric and illegal to the British authorities. However, he insists on fulfilling it in order to accentuate "the dictum of his community's existential narrative ... and to reorient the community's desire for alternative subjectivity" (Ampka 29).

Breaking that obligation, according to the Yoruba culture and spiritual rituals means that there will be a horrific disruption of the cosmic order of the universe and they (Yoruba people) would face a future of vagueness, chaos and doubt. Thus, the Yoruba community represented in Iyaloja and PraiseSinger blame Elesin as well as Pilkings for such approachable mess: Elesinis attached to the Earthly life and refuses fulfilling his spiritual obligations. Hence, Olunde, Elesin and Iyaloja's son who has returned from England to Nigeria, spontaneously takes the responsibility and commits that ritual suicide to maintain his family's honor and the order of universe. The following dialogue between Elesin and Iyaloja is significant:

Elesin: I don't ask you to take pity on me Iyaloja. You have a message for me or you would not have come.

Iyaloja: You made so bold with the servant of the white king who took your side against death. I must tell your brother chiefs when I return how bravely you waged war against him. Especially with words. Iyaloja visits Elesin in jail in order to give him a message that informs him with crucial news. It is noticed that Iyaloja is angry about Elesin's disgraceful deed of not fulfilling his ritual physically and that his action is so dull if compared to his deep speeches about death, honor and bravery.

However, Elesin replies to Iyaloja that he lacks the power and insistence to retrieve his will of committing suicide. He fears death and he is not ready for such moment that ends him up into the land of Fleshless and corpses. He is too earthy to die. Although he has summoned to do that epic ritual orally but he, indeed, has been struggling to make it true: 
Elesin: My powers deserted me. My charms, my spells, even my voice lacked strength when I made to summon the powers that would lead me over the last measure of earth

into the land of the fleshless. You saw it, Iyaloja. You saw me struggle to retrieve my will from the power of the stranger whose shadow fell across the doorway and left me floundering and blundering in a maze I had never before encountered. (Soyinka 68)

This dialogue represents Elesin's truthful moment. He could not hold it anymore to hide his feelings regarding the rituals. Thus, Iyaloja accuses Elesin of betrayal because he knows the evil they are about to face because of his coward deed. She tells him that the King's spirit cannot rest in its final place because of his betrayal to them:

Iyaloja: You will. (Passionately) But this is one oath he cannot shirk. White one, you have a king here, a visitor from your land. We know of his presence here. Tell me, were he to die would you leave his spirit roaming restlessly on the surface of earth? Would you bury him here among those you consider less than human? In your land have you no ceremonies of the dead? (Soyinka 71)

The next phase is the "ritual ceremony" through which Olunde's moment of fulfilling that ritual instead of his father (Elesin) happens to secure his people's safety. The following quotation shows Olunde's ritual of death:

(The women enter, intoning the dirge 'Ale; le; le;' and swaying from side to side. On their shoulders is borne a longish object roughly like a cylindrical bolt, covered in cloth. They set it down on the spot where Iyaloja had stood earlier, and form a semi-circle round it. The PraiseSinger and

Drummer stand on the inside of the semi-circle but the drum is not used at all. The Drummer intones under the (Praise- Singer' invocations.)

Pilkings (as they enter): What is that?

Iyaloja: The burden you have made white one, but we bring it in peace. Pilkings: I said what is it?

Elesin: White man, you must let me out. I have a duty toper form. 
Pilkings: You'll do what you need to do from inside there or not at all. (Soyinka 73).

Iyalojais is overwhelmed for her son's sacrifice because he is still young. She accuses Pilkings of that burden that has taken place. If he has let Elesin does that ritual, he would have saved Olunde from that end. Iyaloja then informs Elesin

Yaljola: They have slain the favourite horse of the king and slain his dog. They have borne them from pulse to pulse centre of the land receiving prayers for their king. But the

rider has chosen to stay behind. Is it too much to ask that he speak his heart to heart of the waiting courier? (Pilkings turns his back on her) So be it. Elesin Oba, you see how even the mere leavings are denied you. (Soyinka 74)

Here, Iyaloja means to belittle Elesin by mentioning that the late king's horse and dog are braver than him; they have had the honor to receive the prayers for the king but he is still here sticking to that mortal earthly world.

Praise - Singer acts as a mediator between the earthly and the spiritual world of gods. He urges Elesin to die so that he does not lose his final request to be accepted and pardoned by gods. He tells him that his son (Olunde) has sacrificed his earthly existence so that he does not let the evil strangers distort his people of Yoruba's future:

Praise- Singer: Elesin, we placed the reins of the world in your hands yet you watched it plunge over the edge of the bitter precipice. You sat with folded arms while evil strangers tilted the world from its course and crashed it beyond the edge of emptiness - you muttered, there is little that one man can do, you left us floundering in a blind future. Your heir has taken the burden on himself. What the end will be, we are not gods to tell. (Soyinka 75)

Olunde's ritual of death is metadramatic; it shows the ceremony of death ritual as an honorable duty and indispensable part of Yoruba spiritual identity. However, the climax of the magnificent use of the metadramatic device of 
'ceremony within the play' lies in the moment of Elesin's suicide after seeing his son's corpse. He has done so in order to condemn his soul to a degraded existence:

(Elesin) has stood rock-still, his knuckles taut on the bars, his eyes glued to the body of his son ...

Suddenly Elesin flings one arm round his neck, once, and with the loop of the chain, strangles himself in a swift, decisive pull.

The guards rush forward to stop him but they are only in time to let his body down. (Soyinka 75)

The way Soyinka has depicted that ceremonial scene of committing the death ritual over the death of the Yoruba king is too detailed and long; that ceremony within the play is well- accentuated from the beginning of Scene $\mathrm{V}$ till the end of it. It starts with Elesin's moment of confrontation with his wife Iyaloja, then Olunde (Elesin's son) commits that ritual ceremony instead of his father in an epic description not for only Olunde, but also for the surroundings of that ceremony such as the presence of women swaying from side to side and drumming. Then, Soyinka ends up that ceremony with profound depiction for Elesin Oba's suicide. His eyes do not quit looking at his son's body, he feels guilty that he is the reason for his son's death. Thus, he kills himself as a kind of relief for his soul. It can be said that Elesin can be compared to any of Shakespeare's tragic heroes. He knows his faults but he dodges the conditions. However, he fails and falls at the end as a result of his deeds. Kemi Atanda Ilori, in Death, Liminality and Postcolonial Identity assures that Elesin's ritual death is felt before the actual happening of it, as Elesin starts the ritual "as a kind of carnival in which he as the Death-figure roams the precincts, completely undisguised, inviting acknowledgement and celebration of his impending death as a form of hero-sacrifice" (21).

In conclusion, it can be argued that Soyinka has successfully used the metadramtic techniques of "role-playing within the play"; "real- life reference", and "ceremonies within the play" in Death and the king's 
Horseman. It can be argued that these techniques can be regarded as effective theatrical mechanisms to accentuate the Yoruba cultural identity through celebration, patriotism, spirituality, and ceremonies of death. By exposing the cultural clash between the African people and Europeans, Soyinka aims to create a space for reciprocal understanding. 


\section{Works Cited}

"The Nobel Prize in Literature 1986: Wole Soyinka." Nobelprize.org, 19 Dec. 2020, www.nobelprize.org/prizes/literature/1986/soyinka/facts/.

Abel, Lionel. Metatheatre: a New View of Dramatic Form. Literary Licensing, 2012.

Ampka, Awam. Theatre and Postcolonial Desires. 1st ed., Routledge (Tylor @ Francis Group), 2004.

Anwar, Nadia. "Dynamics of Distancing in Nigerian Drama - A Functional Approach to Metatheatre."University of Management and Technology, Ibidem Press, Stuttgart, 2016.

Boluwaduro, Eniola. "Names as Cultural Reflections in Wole Soyinka's Death and the King's Horseman." Journal of the Linguistic Association of Nigeria (JOLAN), vol. 21, no. 1, 2018, pp. 97-109.

Calderwood, James L. Metadrama in ShakespearesHenriad: Richard II to Henry V. UMI Books on Demand, 1996.

Cowen, Tyler. "British Colonialism in Nigeria." Marginal Revolution, 4 Mar. 2020, 12:40 am, marginalrevolution.com /marginal revolution /2020/03/british-colonialism-in-nigeria.html.

Falola, Toyin O. "Nigeria as a Colony." Encyclopedia of Britannica, www.britannica.com/place/Nigeria/Military-regimes-1983-99.

Gates Jr., Henry Louis. "Being, the Will and the Semantics of Death." Death and the King's Horseman: Authoritative Text: Backgrounds and 
Contexts, Criticism. 1st ed. New York: Norton Critical Editions, 2003. pp. 75 .

Gupta, Saurav Sen. "The Aesthetics of Action: The Dramatic Art of WoleSoyinka ."University of North Bengal, University of North Bengal, 2005.

Hornby, Richard. Drama, Metadrama and Perception.Bucknell University Press, 1986

Ilori, Kemi Atanda. "Death, Liminality \& Postcolonial Identity."The Theatre of Wole Soyinka. $2^{\text {nd }}$ ed., Leeds: Universal Books UK, 2017. pp.21.

Kassem, Salsabeel. Wole Soyinka. Bibliotheca Alexandrina, Bibliotheca Alexandrina, www.bibalex.org .

Markham, James M. "Soyinka, Nigerian Dramatist, Wins Nobel Literature Prize." The New York Times, 17 Oct. 1986, www.nytimes.com/1986/10/17/books/soyinka-nigerian-dramatist-winsnobel-literature-prize.html.

Minter, Jennifer. "Fearless Writer Revealed the Lives behind the Sorry Day Stories of Dispossession." English Works, 26 Apr. 2014, 3:00 AM, www.englishworks.com.au/social-context/.

Nellhaus, Tobin. "Social Ontology and (Meta) theatricality: Reflexions on Performance and Communication in History." Journal of Dramatic Theory and Criticism. pp.6

Podollan, Christine. "Wole Soyinka: Death and the King's Horseman." The Literary Encyclopedia, 22 Mar. 2004, www.litencyc.com/php /sworks.php?rec=true $\&$ UID=5727. 
Puchner, Martin. Introduction.Tragedy and Metatheatre: Essays on Dramatic Form. Holmes \& Meier, 2003.

Slater, Niall W. Spectator Politics: Metatheatre and Performance in Aristophanes. 1st ed., University of Pennsylvania, 2002.

Soyinka, Wole. Death and the King's Horseman. First ed., Hill and Wang, 1975.

Stanford, Simon. "Wole Soyinka - Interview." Nobel Prize, Nobelprize.org, 28 Apr. 2005, www.nobelprize.org/prizes/literature/1986/soyinka /interview/. Accessed 20 Jan. 2021. 